\title{
Characterization of Central Inhibitory Muscarinic Autoreceptors by the Use of Muscarinic Acetylcholine Receptor Knock-Out Mice
}

\author{
Weilie Zhang, ${ }^{1}$ Anthony S. Basile, ${ }^{1}$ Jesus Gomeza, ${ }^{1}$ Laura A. Volpicelli, ${ }^{2}$ Allan I. Levey, ${ }^{2}$ and Jürgen Wess ${ }^{1}$ \\ ${ }^{1}$ Laboratory of Bioorganic Chemistry, National Institute of Diabetes and Digestive and Kidney Diseases, Bethesda, \\ Maryland 20892, and 2Department of Neurology, Emory University School of Medicine, Atlanta, Georgia 30322
}

Forebrain muscarinic acetylcholine (ACh) receptors (mAChRs; $\left.\mathrm{M}_{1}-\mathrm{M}_{5}\right)$ are predicted to play important roles in many fundamental central functions, including higher cognitive processes and modulation of extrapyramidal motor activity. Synaptic ACh levels are known to be regulated by the activity of presynaptic muscarinic autoreceptors mediating inhibition of ACh release. Primarily because of the use of ligands with limited receptor subtype selectivity, classical pharmacological studies have led to conflicting results regarding the identity of the mAChR subtypes mediating this activity in different areas of the brain. To investigate the molecular identity of hippocampal, cortical, and striatal inhibitory muscarinic autoreceptors in a more direct manner, we used genetically altered mice lacking functional $\mathrm{M}_{2}$ and/or $\mathrm{M}_{4}$ mAChRs [knock-out (KO) mice]. After labeling of cellular ACh pools with $\left[{ }^{3} \mathrm{H}\right]$ choline, potassium-stimulated $\left[{ }^{3} \mathrm{H}\right] \mathrm{ACh}$ release was measured in superfused brain slices, either in the absence or the presence of muscarinic drugs. The

Many of the important central actions of acetylcholine (ACh) are mediated by members of the muscarinic ACh receptor family $\left(\mathrm{M}_{1}-\mathrm{M}_{5}\right)$ that belong to the superfamily of G-protein-coupled receptors (Hulme et al., 1990; Wess, 1996). Central mAChRs are involved in a large number of important physiological functions, including the control of extrapyramidal locomotor activity (Di Chiara et al., 1994) and higher cognitive processes such as learning and memory (Coyle et al., 1983; Mash et al., 1985; Quirion et al., 1989). Identification of the $\mathrm{mAChR}$ subtypes involved in these diverse central muscarinic functions has proven a difficult task, primarily because of the lack of ligands with pronounced subtype selectivity (Buckley et al., 1989; Dörje et al., 1991; Caulfield, 1993; Wess, 1996) and the fact that most central tissues express multiple mAChRs (Levey, 1993; Vilaro et al., 1993).

As is the case with many other neurotransmitter systems, synaptic levels of ACh are known to be regulated by the activity of presynaptic mAChRs mediating feedback inhibition of ACh release from cholinergic nerve terminals (for review, see Kilbinger,

\footnotetext{
Received Oct. 19, 2001; revised Dec. 4, 2001; accepted Dec. 6, 2001.

This work was supported by a Cooperative Research and Development Alliance between the National Institute of Diabetes and Digestive and Kidney Diseases (J.W.) and the Eli Lilly Research Laboratories, National Institutes of Health Grant NS30454 (A.L.), and the Alzheimer Association (A.L.). We thank A. Duttaroy, F. P. Bymaster, D. L. Mckinzie, and C. C. Felder for helpful discussions.

Correspondence should be addressed to Dr. Jürgen Wess, Molecular Signaling Section Laboratory of Bioorganic Chemistry, National Institutes of Health, National Institute of Diabetes and Digestive and Kidney Disease, Building 8A, Room B1A05, 8 Center Drive, MSC 0810, Bethesda, MD 20892-0810. E-mail: jwess@ helix.nih.gov.

J. Gomeza's present address: Max-Planck-Institut für Hirnforschung, Neurochemie, Deutschordenstrasse 46, D-60528 Frankfurt/Main, Germany.

Copyright (C) 2002 Society for Neuroscience $\quad 0270-6474 / 02 / 221709-09 \$ 15.00 / 0$
}

nonsubtype-selective muscarinic agonist, oxotremorine $(0.1-10 \mu \mathrm{M})$, inhibited potassium-stimulated $\left[{ }^{3} \mathrm{H}\right] \mathrm{ACh}$ release in hippocampal, cortical, and striatal slices prepared from wildtype mice by up to $80 \%$. This activity was totally abolished in tissues prepared from $\mathrm{M}_{2}-\mathrm{M}_{4}$ receptor double $\mathrm{KO}$ mice. Strikingly, release studies with brain slices from $\mathrm{M}_{2}$ and $\mathrm{M}_{4}$ receptor single $\mathrm{KO}$ mice indicated that autoinhibition of $\mathrm{ACh}$ release is mediated primarily by the $M_{2}$ receptor in hippocampus and cerebral cortex, but predominantly by the $\mathrm{M}_{4}$ receptor in the striatum. These results, together with additional receptor localization studies, support the novel concept that autoinhibition of ACh release involves different mAChRs in different regions of the brain.

Key words: acetylcholine release; autoreceptors; knockout mice; muscarinic receptors; oxotremorine; presynaptic receptors

1984; Starke et al., 1989). In situ mRNA hybridization studies have shown that all five mAChRs are expressed in areas of the CNS known to contain cholinergic cell bodies, raising the possibility that multiple mAChRs participate in presynaptic modulation of ACh release (Vilaro et al., 1994). Functional studies using classical pharmacological tools (muscarinic agonists and antagonists) have led to conflicting results regarding the molecular nature of the mAChRs mediating autoinhibition of ACh release. For example, inhibitory muscarinic autoreceptors in the hippocampus have been classified as either $\mathrm{M}_{2}$ (Pohorecki et al., 1988; Lapchak et al., 1989), $\mathrm{M}_{3}$ (Raiteri et al., 1989), or $\mathrm{M}_{4}$ (McKinney et al., 1993) receptors, or as mixtures of $\mathrm{M}_{1}$ and $\mathrm{M}_{4}$ mAChRs (Vannucchi and Pepeu, 1995). Similarly, it has been proposed that striatal muscarinic autoreceptors predominantly consist of either $\mathrm{M}_{1}$ (Kawashima et al., 1991), $\mathrm{M}_{2}$ (James and Cubeddu, 1987; Lapchak et al., 1989; Weiler, 1989; Billard et al., 1995), $\mathbf{M}_{3}$ (De Boer et al., 1990; Büyükuysal et al., 1998), or $\mathbf{M}_{4}$ (Dolezal and Tucek, 1998) receptors. It is likely that these discrepant results are primarily caused by the limited subtype selectivity of the pharmacological agents used in these studies (Buckley et al., 1989; Dörje et al., 1991; Caulfield, 1993).

To circumvent these difficulties, we and others recently developed mutant mouse lines in which specific mAChR genes had been inactivated via gene-targeting techniques (Hamilton et al., 1997; Gomeza et al., 1999a,b; Yamada et al., 2001). Using these mice, we performed systematic studies of $\mathrm{ACh}$ release from brain slices, to examine the molecular nature of central muscarinic autoreceptors in a more direct manner. Specifically, we studied muscarinic agonist-mediated inhibition of potassium-stimulated $\left[{ }^{3} \mathrm{H}\right] \mathrm{ACh}$ re- 
lease using superfused hippocampal, cortical, and striatal tissues from $\mathrm{M}_{2}$ and $\mathrm{M}_{4}$ receptor single knock-out (KO) mice (Gomeza et al., 1999a,b) and $\mathrm{M}_{2}-\mathrm{M}_{4}$ receptor double KO mice (A. Duttaroy, J. Gomeza, and J. Wess, unpublished observations).

\section{MATERIALS AND METHODS}

Animals. The generation of homozygous $\mathrm{M}_{2}$ receptor KO (genetic background: $129 \mathrm{~J} 1 \times \mathrm{CF} 1)$ and $\mathrm{M}_{4}$ receptor $\mathrm{KO}(129 / \mathrm{SvEv} \times \mathrm{CF} 1)$ mice has been described previously (Gomeza et al., 1999a,b). $\mathrm{M}_{2}-\mathrm{M}_{4}$ receptor double KO mice $(129 \mathrm{~J} 1 \times 129 \mathrm{SvEv} \times \mathrm{CF} 1)$ were generated by intermating homozygous $\mathrm{M}_{2}{ }^{-1-}$ and $\mathrm{M}_{4}{ }^{-1-}$ receptor mutant mice (A. Duttaroy, J. Gomeza, and J. Wess, unpublished observations). In all experiments, aged-matched wild-type (WT) mice of the matching genetic background were used as control animals. Mouse genotyping was performed by PCR analysis of mouse tail DNA.

Acetylcholine release studies. Mice (males; 2-4 months old) were killed by decapitation, and brains were removed. Hippocampi, cortices, and striata were dissected and chopped into $250 \mu \mathrm{m}$ prisms using a Sorvall tissue chopper (Newton, CT). Hippocampal, cortical, and striatal slices prepared from one mouse were dispersed in $25 \mathrm{ml}$ of oxygenated $(95 \%$ $\mathrm{O}_{2}$ and 5\% $\mathrm{CO}_{2}$ ) Krebs'-Ringer's solution buffer, $\mathrm{pH} 7.4$ (in mm: 11.5 glucose, $25 \mathrm{NaHCO}_{3}, 1.2 \mathrm{MgCl}_{2}, 1.2 \mathrm{NaH}_{2} \mathrm{PO}_{4}, 118 \mathrm{NaCl}, 4.8 \mathrm{KCl}, 2.5$ $\mathrm{CaCl}_{2}$ and $0.004 \mathrm{Na}_{2}$-EDTA) at $33^{\circ} \mathrm{C}$ for $20 \mathrm{~min}$. Slices were then incubated with $\left[{ }^{3} \mathrm{H}\right]$ choline $(75 \mathrm{Ci} / \mathrm{mmol}$; NEN Life Sciences Products, Boston, MA) at a final concentration of $0.1 \mu \mathrm{M}$ for $30 \mathrm{~min}$. This low concentration of $\left[{ }^{3} \mathrm{H}\right]$ choline favors the selective uptake of choline only into cholinergic neurons through their high-affinity uptake system (Pittel et al., 1990). After rinsing, slices were transferred to a superfusion system (SF-12; Brandel, Gaithersburg, MD) and superfused at $33^{\circ} \mathrm{C}$ at a constant rate of $0.4 \mathrm{ml} / \mathrm{min}$ with Krebs'-Ringer's solution buffer containing $10 \mu \mathrm{M}$ hemicholinium to prevent uptake of $\left[{ }^{3} \mathrm{H}\right]$ choline during the release experiments. Fractions were collected every 4 min beginning after a 60 min superfusion. Two 2 min periods of 25,30 , or $20 \mathrm{~mm} \mathrm{KCl}$ (hippocampus, cerebral cortex, and striatum, respectively) were applied after 72 (S1) and 104 (S2) min of superfusion. Tetrodotoxin (600 nM) (Sigma, St. Louis, MO) was added at the beginning of the superfusion period where indicated. Drugs were added to the superfusion buffer 20 min before S2. The efflux of tritium collected was calculated as a percentage of the total tritium present in the slices at the start of the fraction considered. The net efflux of tritium was calculated by subtracting the average of three fractions (expected basal value) before $\mathrm{KCl}$ stimulation. The results were expressed as the S2:S1 ratio of release.

Separation of $\left[{ }^{3} H\right]$ choline and $\left[{ }^{3} H\right] A C h$ by reverse-phase HPLC. Hippocampal, cortical, and striatal slices prepared from $\mathrm{M}_{4}$ receptor WT mice were incubated with $\left[{ }^{3} \mathrm{H}\right]$ choline $(75 \mathrm{Ci} / \mathrm{mmol})$, superfused, and simulated with $\mathrm{KCl}$ as described in the previous paragraph. To prevent enzymatic degradation of released ACh, physostigmine $(100 \mu \mathrm{M})$ was added to the superfusion medium. Fractions were collected every $4 \mathrm{~min}$ (rate of superfusion: $0.4 \mathrm{ml} / \mathrm{min}$ ), as described above. $\left[{ }^{3} \mathrm{H}\right]$ choline and $\left[{ }^{3} \mathrm{H}\right] \mathrm{ACh}$ were separated by reverse-phase HPLC followed by liquid scintillation spectrometry, essentially as described (Wessler and Werhand, 1990). Aliquots of each fraction $(100 \mu l)$ were injected onto the HPLC (ESA Inc., Chelmsford, MA; 582; reverse phase C18 5U column, $250 \times 3.2 \mathrm{~mm})$. The elution solvent consisted of $0.1 \mathrm{M}$ phosphate buffer, $\mathrm{pH} 4.7$, that contained methanol $(8 \% \mathrm{vol})$ and $0.2 \mathrm{~mm}$ tetramethylammonium. The flow rate was $0.5 \mathrm{ml} / \mathrm{min}$, and the effluent was collected in $1 \mathrm{~min}$ fractions. The retention times of choline and ACh were determined using the radioactive standards $\left[{ }^{3} \mathrm{H}\right]$ choline and $\left[{ }^{14} \mathrm{C}\right] \mathrm{ACh}(20$ $\mathrm{Ci} / \mathrm{mmol}$; ARC, St. Louis, MO) (Fig. $1 A$ ).

Muscarinic receptor-vesicular acetylcholine transporter colocalization studies. Mice were injected with heparin, anesthetized with sodium pentobarbital, and perfused transcardially with $15-20 \mathrm{ml} 0.9 \% \mathrm{NaCl}$ and $0.005 \%$ sodium nitroprusside, followed by $80-120 \mathrm{ml}$ of $4 \%$ paraformaldehyde in $0.1 \mathrm{~m}$ phosphate buffer. The brain was removed and placed in $4 \%$ paraformaldehyde overnight at $4^{\circ} \mathrm{C}$. Sections $(\sim 50-\mu \mathrm{m}$-thick) of the striatum were cut on a vibrating microtome and rinsed several times in PBS. All solutions were diluted in PBS, and all incubations were performed at room temperature with gentle agitation. The sections were treated with $3 \%$ hydrogen peroxide for $10 \mathrm{~min}$, followed by three rinses in PBS and blocking in 5\% normal goat serum, $5 \%$ normal horse serum, and $10 \mu \mathrm{g} / \mathrm{ml}$ avidin for $30 \mathrm{~min}$. Incubations with primary antibodies were performed in buffer containing $1 \%$ normal goat serum, $1 \%$ normal horse serum, and $50 \mu \mathrm{g} / \mathrm{ml}$ biotin. The following antibodies were used (Levey et al., 1991; Hersch et al., 1994; Gilmor et al., 1996; Bernard et al.,
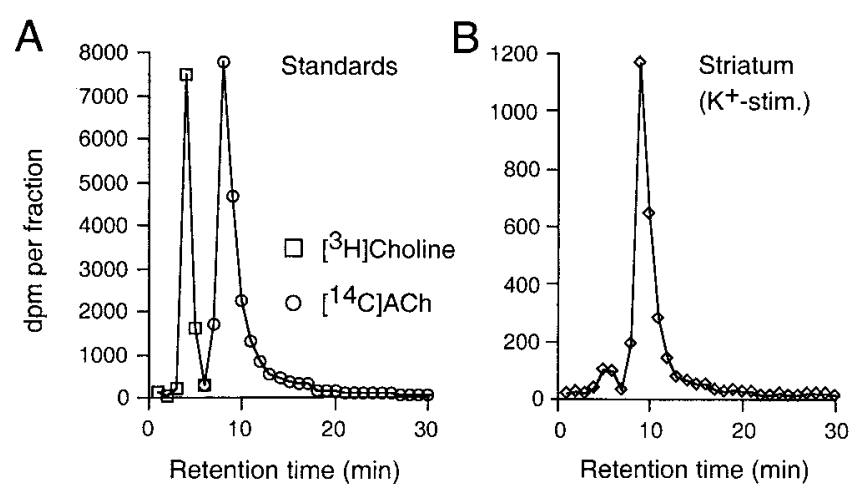

Figure 1. Separation of radiolabeled choline and ACh by reverse-phase HPLC followed by liquid scintillation spectrometry. $A$, Standards. The radiochromatogram shown here was obtained after injection of a solution $(100 \mu \mathrm{l})$ that contained $11,590 \mathrm{dpm}\left[{ }^{3} \mathrm{H}\right]$ choline and $24,850 \mathrm{dpm}$ $\left[{ }^{14} \mathrm{C}\right] \mathrm{ACh}$. When the two radiolabeled compounds were injected alone, the retention times were similar to those observed in the coinjection experiments (data not shown). $B$, Representative radiochromatogram showing $\mathrm{KCl}$-dependent $\left[{ }^{3} \mathrm{H}\right]$ choline and $\left[{ }^{3} \mathrm{H}\right] \mathrm{ACh}$ release from striatal slices from WT mice. Superfused striatal slices prepared from $\mathrm{M}_{4}$ receptor WT mice were prelabeled with $\left[{ }^{3} \mathrm{H}\right]$ choline and stimulated with $\mathrm{KCl}$ as described in Materials and Methods. The superfusion medium contained $100 \mu \mathrm{M}$ physostigmine. The depicted radiochromatogram was obtained after injection of $100 \mu \mathrm{l}$ of the fraction (fraction 5) collected immediately after $\mathrm{K}^{+}$stimulation (total $\left[{ }^{3} \mathrm{H}\right]$ content of the $100 \mu$ l aliquot: $3223 \mathrm{dpm})$. Note that $>90 \%$ of the $\left[{ }^{3} \mathrm{H}\right]$ outflow represents authentic $\left[{ }^{3} \mathrm{H}\right] \mathrm{ACh}$.

1998, 1999): $\mathbf{M}_{2}$ rat monoclonal antibody (1:100), $\mathbf{M}_{4}$ mouse monoclonal antibody (1:1000), and vesicular acetylcholine transporter (VAChT) rabbit polyclonal antibody $(1 \mu \mathrm{g} / \mathrm{ml})$. The specificity of these antibodies has been described in detail previously (Levey et al., 1991; Hersch et al., 1994; Gilmor et al., 1996; Bernard et al., 1998, 1999). For muscarinic receptor-VAChT double-labeling studies, striatal slices were coincubated with the two primary antibodies. The sections were then rinsed and incubated for 60 min with donkey anti-rabbit rhodamine red-X (1:100; Jackson ImmunoResearch, West Grove, PA) in secondary buffer (1\% normal goat serum and $1 \%$ normal horse serum). Subsequently, sections were rinsed and incubated with biotinylated goat anti-mouse or anti-rat secondary antibody (1:100; Jackson ImmunoResearch) in secondary buffer for $60 \mathrm{~min}$. After several rinses, the sections were incubated with avidin-biotin complex (ABC elite; Vector Laboratories, Burlingame, $\mathrm{CA}$ ) for $60 \mathrm{~min}$, rinsed, and incubated in tyramide-fluorescein diluted in amplification diluent $(1: 100$; NEN) for $10 \mathrm{~min}$. The sections were rinsed and incubated for $30 \mathrm{~min}$ in $10 \mathrm{~mm}$ cupric sulfate in $50 \mathrm{~mm}$ ammonium acetate, $\mathrm{pH}$ 5.0, to eliminate autofluorescence (Schnell et al., 1999). After rinsing, sections were mounted using Vectashield mounting media for fluorescence (Vector Laboratories). Control incubations included omission of the primary antibodies to test for nonspecific binding of the secondary antibodies and incubation with one primary but both secondary antibodies to demonstrate the absence of bleedthrough and cross-labeling.

Sections were scanned using a Zeiss (Oberkochen, Germany) LSM 510 laser-scanning confocal microscope coupled to a Zeiss $100 \mathrm{M}$ axiovert and a $63 \times$ Plan-Apochromat oil-immersion lens. Quantitation of colocalization between $\mathrm{M}_{2}$ or $\mathrm{M}_{4}$ muscarinic receptors and VAChT was analyzed using Metamorph Imaging System Software (Universal Imaging Corporation, West Chester, PA). To define background, sections incubated with both secondary but no primary antibodies were used, and the average grayscale pixel intensity +1 SD was measured in the FITC and rhodamine channels. To subtract background from double-labeled images, the threshold of each channel was set at the value obtained for background. The average pixel intensity $+1 \mathrm{SD}$ was measured, and the threshold was set to this new value. The percentage of the area of overlap between $\mathrm{M}_{2}$ (or $\mathrm{M}_{4}$ ) pixels over VAChT pixels was measured. Colocalization was assessed on four randomly chosen fields of the striatum from three different animals per genotype. Data are presented as means $( \pm$ SEM).

Statistics. All data were analyzed by one-way repeated measures ANOVA followed by a Student-Newman-Keuls test. Data are given as means \pm SEM. 
Table 1. Basal and potassium-evoked release of $\left[{ }^{3} \mathrm{H}\right]$ choline and $\left[{ }^{3} \mathrm{H}\right] \mathrm{ACh}$ in hippocampal, cortical, and striatal slices from WT mice prelabeled with $\left[{ }^{3} \mathrm{H}\right]$ choline, as determined by reverse-phase HPLC

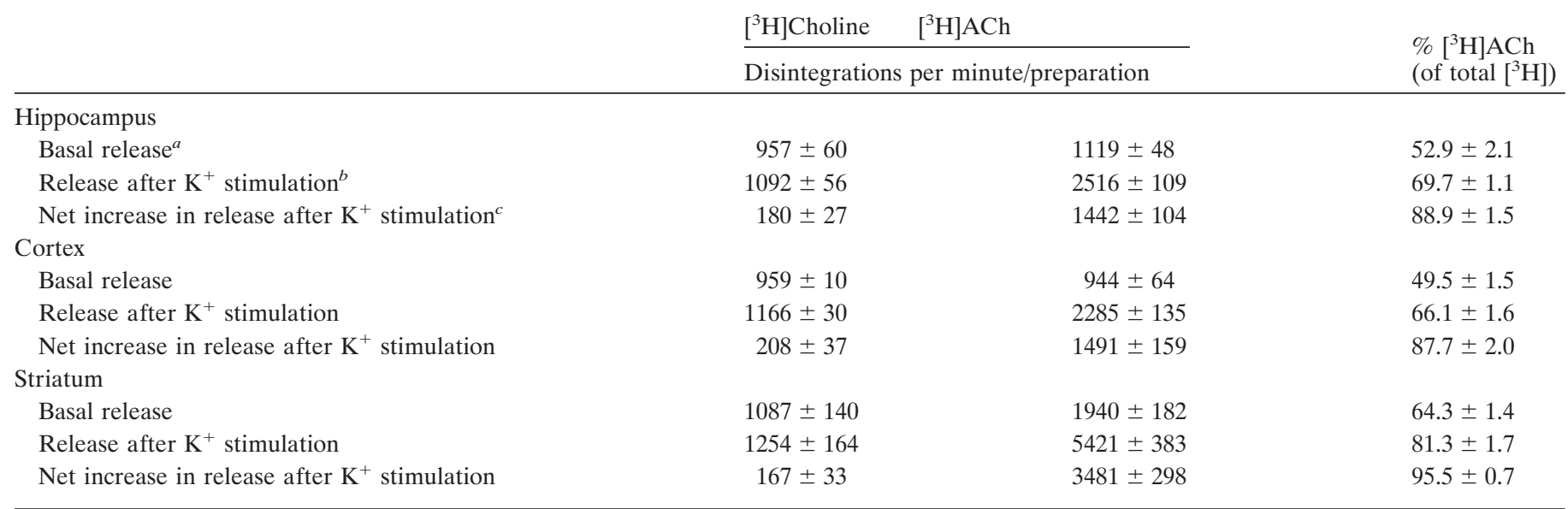

${ }^{a}$ Sum of disintegrations per minute of aliquots $(100 \mu \mathrm{l})$ taken from the three fractions collected immediately before $\mathrm{K}^{+}$stimulation (fractions 2-4).

${ }^{b}$ Sum of disintegrations per minute of aliquots $(100 \mu \mathrm{l})$ taken from the three fractions collected immediately after $\mathrm{K}^{+}$stimulation (fractions 5-7).

${ }^{c}\left(\left[{ }^{3} \mathrm{H}\right]\right.$ outflow after $\mathrm{K}^{+}$stimulation) - (basal $\left[{ }^{3} \mathrm{H}\right]$ outflow).

Tissue slices derived from WT mice $\left(\mathrm{M}_{4}\right.$ receptor WT mice) were prelabeled with $\left[{ }^{3} \mathrm{H}\right]$ choline $(0.1 \mu \mathrm{M})$, and potassium-stimulated release of [ $\left.{ }^{3} \mathrm{H}\right] \mathrm{choline}$ and $\left[{ }^{3} \mathrm{H}\right] \mathrm{ACh}$ was determined as described in Materials and Methods. $\left[{ }^{3} \mathrm{H}\right]$ choline and $\left[{ }^{3} \mathrm{H}\right] \mathrm{ACh}$ were separated by reverse-phase HPLC followed by liquid scintillation spectrometry (Wessler and Werhand, 1990). Data represent means \pm SEM from four independent experiments (mice).

\section{RESULTS}

\section{Muscarinic agonist-mediated inhibition of stimulated ACh release is abolished in brain slices from $M_{2}-M_{4}$ receptor double $\mathrm{KO}$ mice}

The $\mathrm{M}_{2}$ and $\mathrm{M}_{4}$ mAChRs are selectively coupled to $\mathrm{G}$-proteins of the $G_{i} / G_{0}$ family, whereas the $M_{1}, M_{3}$, and $M_{5} m A C h R s$ are preferentially linked to G-proteins of the $\mathrm{G}_{\mathrm{q}}$ class (Hulme et al., 1990; Caulfield, 1993; Wess, 1996). Because mAChR-activated $\mathrm{G}_{\mathrm{i}} / \mathrm{G}_{\mathrm{o}}$ proteins mediate the inhibition of voltage-sensitive $\mathrm{Ca}^{2+}$ channels (Caulfield, 1993; Shapiro et al., 1999) that are known to be intimately involved in the regulation of neurotransmitter release, we speculated that the $\mathrm{M}_{2}$ and/or $\mathrm{M}_{4}$ receptor subtypes represent the major inhibitory muscarinic autoreceptors. To test this concept in a direct and unambiguous manner, we initially analyzed ACh release using mutant mice lacking both $\mathrm{M}_{2}$ and $\mathrm{M}_{4}$ mAChRs $\left(\mathrm{M}_{2}-\mathrm{M}_{4}\right.$ double $\mathrm{KO}$ mice) (Duttaroy, Gomeza, and Wess, unpublished observations). The $\mathrm{M}_{2}-\mathrm{M}_{4}$ receptor double KO mice showed no obvious morphological abnormalities and did not differ from their WT littermates in overall health, fertility, and longevity. Moreover, immunoprecipitation studies with receptor subtype-selective antisera indicated that the lack of $\mathrm{M}_{2}$ and $\mathrm{M}_{4}$ receptors did not lead to compensatory changes in the levels of the remaining mAChR subtypes (Duttaroy, Gomeza, and Wess, unpublished observations).

In vitro ACh release studies were performed with superfused hippocampal, cortical, and striatal slices prepared from WT and mAChR mutant mice. Initially, cellular ACh pools were radioactively labeled by incubating brain tissues with $\left[{ }^{3} \mathrm{H}\right]$ choline. Subsequently, potassium-stimulated $\left[{ }^{3} \mathrm{H}\right]$ release was measured either in the absence (S1 phase) or the presence of drugs (S2 phase), as described in Materials and Methods.

To verify that the potassium-dependent $\left[{ }^{3} \mathrm{H}\right]$ outflow in the three different tissues primarily consisted of $\left[{ }^{3} \mathrm{H}\right] \mathrm{ACh}$, we used a reverse-phase HPLC method that can efficiently separate $\left[{ }^{3} \mathrm{H}\right]$ choline and $\left[{ }^{3} \mathrm{H}\right] \mathrm{ACh}$ with a recovery rate of $\sim 100 \%$ (Wessler and Werhand, 1990). To prevent enzymatic degradation of $\left[{ }^{3} \mathrm{H}\right] \mathrm{ACh}$, physostigmine $(100 \mu \mathrm{M})$ was added to the perfusion medium in this set of experiments. Control experiments with $\left[{ }^{3} \mathrm{H}\right]$ choline and $\left[{ }^{14} \mathrm{C}\right] \mathrm{ACh}$ standards indicated that both amines could be clearly separated with virtually no overlap (Fig. $1 A$ ). In hippocampal, cortical, and striatal preparations from WT mice $\left(\mathrm{M}_{4}\right.$ receptor WT mice), the basal (spontaneous) $\left[{ }^{3} \mathrm{H}\right]$ efflux comprised $\sim 36-50 \%\left[{ }^{3} \mathrm{H}\right]$ choline and $\sim 50-64 \%\left[{ }^{3} \mathrm{H}\right] \mathrm{ACh}(\mathrm{Ta}-$ ble 1). After potassium depolarization, the net increase in potassium-dependent $\left[{ }^{3} \mathrm{H}\right.$ ]efflux (efflux after $\mathrm{KCl}$ depolarization - basal efflux) consisted predominantly of $\left[{ }^{3} \mathrm{H}\right] \mathrm{ACh}$ in all three tissues investigated (88-96\% of total net $\left[{ }^{3} \mathrm{H}\right]$ outflow) (Table 1 ). The $\left[{ }^{3} \mathrm{H}\right]$ recovery rate was $\sim 95 \%$ in all three tissues investigated (data not shown). When calcium was omitted from the superfusion medium, the $\mathrm{KCl}$-induced increase in $\left[{ }^{3} \mathrm{H}\right] \mathrm{ACh}$ release was virtually abolished in all three tissues studied $(<10 \%$ of $\left[{ }^{3} \mathrm{H}\right] \mathrm{ACh}$ release observed in the presence of calcium; $\left.n=4\right)$. Consistent with previous studies (Pedata et al., 1986; Marchi et al., 1990), these data indicate that the potassium-stimulated $\left[{ }^{3} \mathrm{H}\right]$ outflow in slices from different central tissues preincubated with $\left[{ }^{3} \mathrm{H}\right]$ choline predominantly represents authentic $\left[{ }^{3} \mathrm{H}\right] \mathrm{ACh}$ (shown for striatal slices in Fig. $1 B$ ). Throughout the text, we therefore refer to potassium-stimulated $\left[{ }^{3} \mathrm{H}\right]$ outflow simply as $\left[{ }^{3} \mathrm{H}\right] \mathrm{ACh}$ release.

Incubation of hippocampal, cortical, and striatal slices from WT mice with oxotremorine (0.1-10 $\mu \mathrm{M})$, a nonsubtype-selective muscarinic agonist, led to a dose-dependent inhibition of stimulated $\left[{ }^{3} \mathrm{H}\right] \mathrm{ACh}$ release (Figs. $2 A, 3 A, 4 A$, top panels). At the highest oxotremorine concentration used $(10 \mu \mathrm{M})$, the average inhibition of $\left[{ }^{3} \mathrm{H}\right] \mathrm{ACh}$ release amounted to $73 \pm 2 \%$ in hippocampal, $74 \pm 4 \%$ in cortical, and $56 \pm 2 \%$ in striatal preparations, respectively. The oxotremorine $(10 \mu \mathrm{M})$-mediated inhibition of transmitter release was completely abolished in the presence of atropine $(2 \mu \mathrm{M})$, confirming the involvement of mAChRs (Figs. $2 A, 3 A, 4 A$ ). Incubation of tissue slices with atropine $(2 \mu \mathrm{M})$ alone had no significant effect on potassiumevoked $\left[{ }^{3} \mathrm{H}\right] \mathrm{ACh}$ release (Figs. $2 A, 3 A, 4 A$ ), suggesting that the 

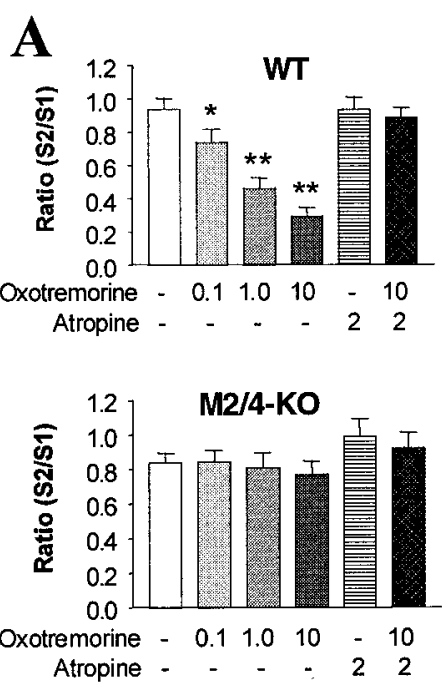

B
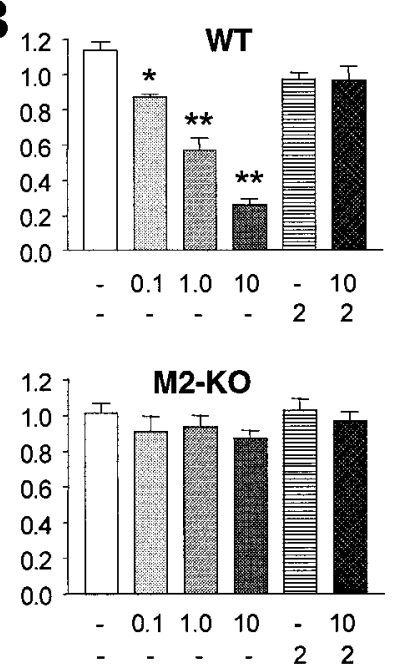
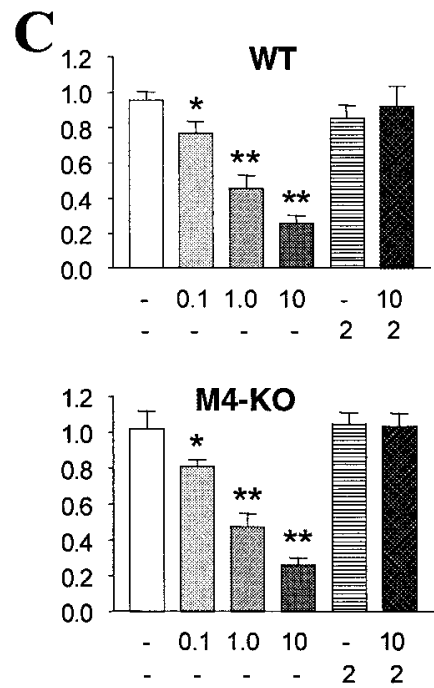

Hippocampus

Figure 2. Effect of oxotremorine on potassium-stimulated $\left[{ }^{3} \mathrm{H}\right] \mathrm{ACh}$ release in hippocampal slices from $\mathrm{M}_{2}-\mathrm{M}_{4}$ receptor double $\mathrm{KO}, \mathrm{M}_{2}$ receptor single $\mathrm{KO}$, and $\mathrm{M}_{4}$ receptor single $\mathrm{KO}$ mice $(A-C$, bottom panels $)$ and their corresponding WT control mice $(A-C$, top panels). Each bar represents the mean \pm SEM of S2/S1 values from 6-11 independent experiments (mice). Concentrations shown are micromolar. Asterisks indicate significant differences from the control group (no drug) $\left({ }^{*} p<0.05 ;{ }^{*} p<0.01\right)$.
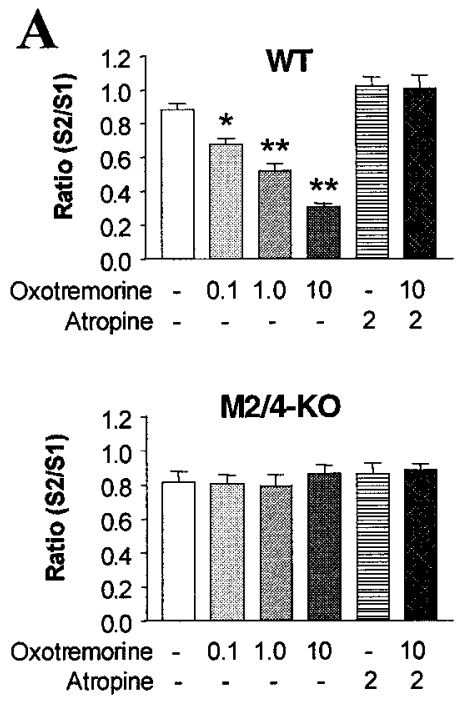

B

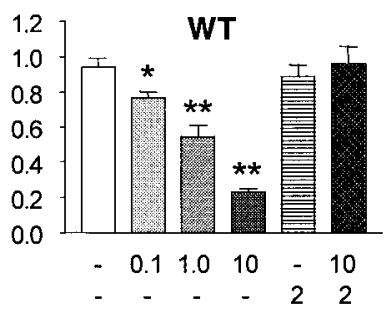

M2-KO

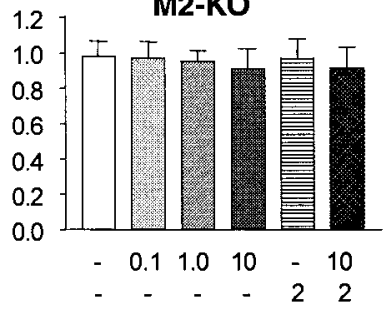

Cortex
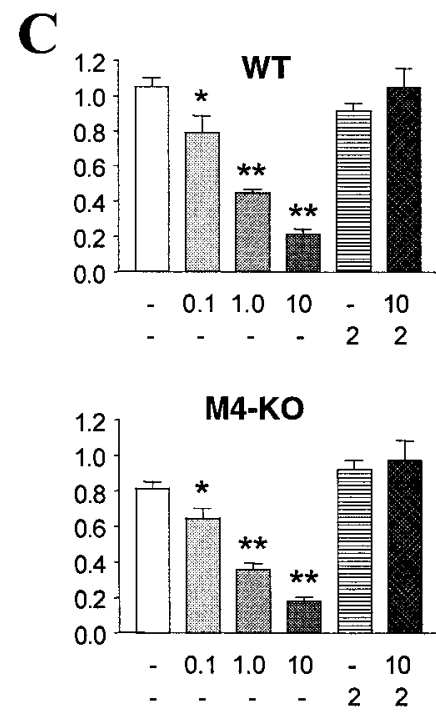

Figure 3. Effect of oxotremorine on potassium-stimulated $\left[{ }^{3} \mathrm{H}\right] \mathrm{ACh}$ release in cortical slices from $\mathrm{M}_{2}-\mathrm{M}_{4}$ receptor double $\mathrm{KO}$, $\mathrm{M}_{2}$ receptor single $\mathrm{KO}$, and $\mathrm{M}_{4}$ receptor single $\mathrm{KO}$ mice $(A-C$, bottom panels $)$ and their corresponding WT control mice $(A-C$, top panels $)$. Each bar represents the mean $\pm \mathrm{SEM}$ of S2/S1 values from 6-11 independent experiments (mice). Concentrations shown are micromolar. Asterisks indicate significant differences from the control group (no drug) $\left({ }^{*} p<0.05 ; * *<<0.01\right)$.

biophase concentration of ACh did not reach levels that were sufficiently high to produce autoinhibition of ACh release. It is likely that degradation of released ACh by cholinesterases (all experiments were carried out in the absence of cholinesterase inhibitors) and removal of ACh by the superfusion stream were the major factors leading to the rapid reduction of synaptic ACh levels (for review, see Starke et al., 1989).

In all three tissues examined, $\mathrm{K}^{+}$-evoked $\left[{ }^{3} \mathrm{H}\right] \mathrm{ACh}$ release and oxotremorine-induced inhibition of stimulated $\left[{ }^{3} \mathrm{H}\right]$ outflow remained essentially unaffected by incubation with tetro- dotoxin $(600 \mathrm{~nm})$ (data not shown), suggesting that agonistdependent inhibition of $\left[{ }^{3} \mathrm{H}\right] \mathrm{ACh}$ release does not require the propagation of nerve impulses. As reviewed by Starke et al. (1989), it is therefore likely that autoinhibition of $\left[{ }^{3} \mathrm{H}\right] \mathrm{ACh}$ release in central tissues is primarily mediated by $\mathrm{mAChRs}$ located directly on cholinergic nerve terminals. Strikingly, in hippocampal, cortical, and striatal slices prepared from $\mathrm{M}_{2}-\mathrm{M}_{4}$ receptor double $\mathrm{KO}$ mice, oxotremorine (0.1-10 $\mu \mathrm{M})$ completely lost its ability to mediate inhibition of stimulated $\left[{ }^{3} \mathrm{H}\right] \mathrm{ACh}$ release (Figs. $2 A, 3 A, 4 A$, bottom panels). This ob- 

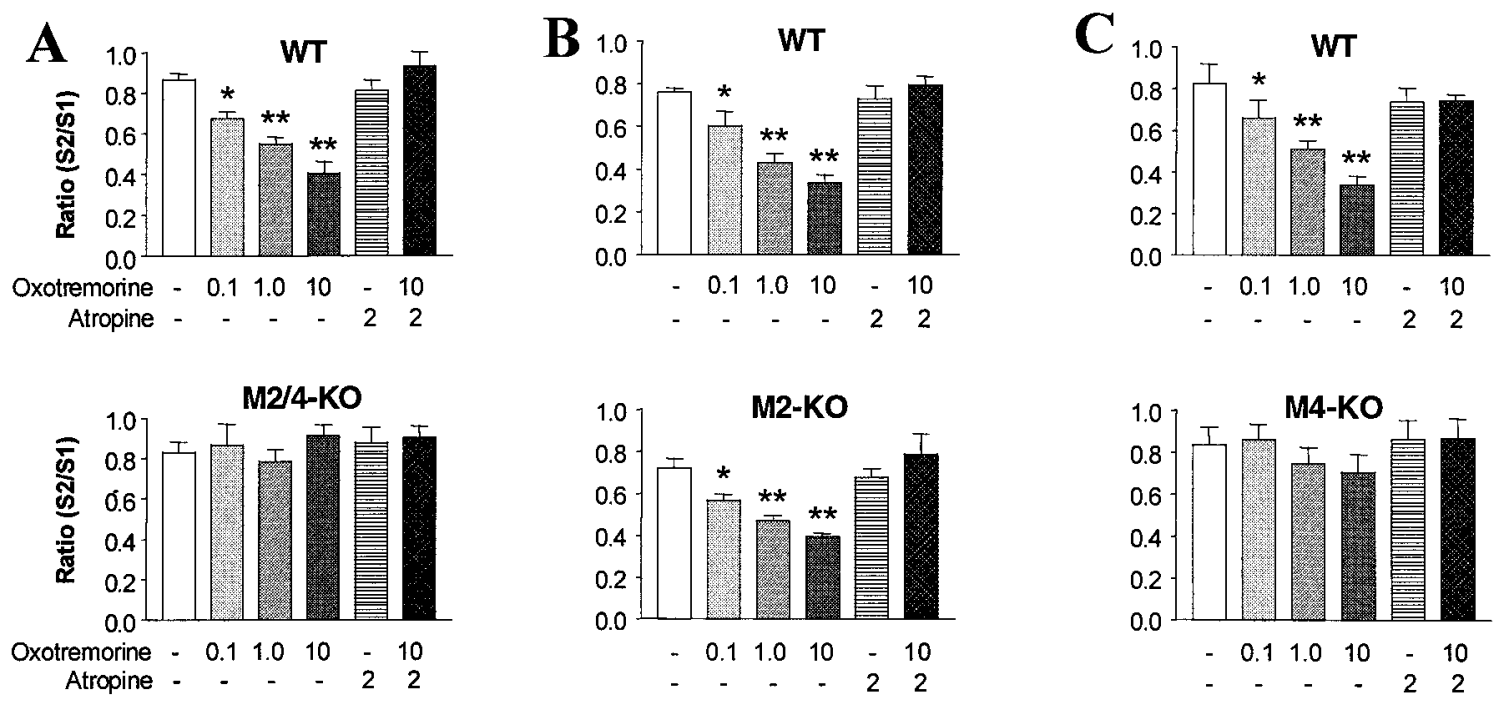

Striatum

Figure 4. Effect of oxotremorine on potassium-stimulated $\left[{ }^{3} \mathrm{H}\right] \mathrm{ACh}$ release in striatal slices from $\mathrm{M}_{2}-\mathrm{M}_{4}$ receptor double $\mathrm{KO}$, $\mathrm{M}_{2}$ receptor single $\mathrm{KO}$, and $\mathrm{M}_{4}$ receptor single $\mathrm{KO}$ mice $(A-C$, bottom panels $)$ and their corresponding WT control mice $(A-C$, top panels $)$. Each bar represents the mean $\pm \mathrm{SEM}$ of S2/S1 values from 6-11 independent experiments (mice). Concentrations shown are micromolar. Asterisks indicate significant differences from the control group (no drug) $(* p<0.05 ; * p<0.01)$.

servation demonstrates in a very convincing manner that $\mathbf{M}_{2}$ and/or $\mathrm{M}_{4}$ receptors mediate autoinhibition of ACh release in these brain tissues.

\section{The $M_{2}$ subtype represents the predominant} muscarinic autoreceptor in hippocampus and cerebral cortex

To examine the relative contributions of $\mathrm{M}_{2}$ and $\mathrm{M}_{4}$ receptors to autoinhibition of stimulated $\mathrm{ACh}$ release, we next performed analogous studies with hippocampal and cortical tissues from $\mathrm{M}_{2}$ and $\mathrm{M}_{4}$ receptor single $\mathrm{KO}$ mice and their corresponding WT controls. Interestingly, oxotremorine $(0.1-10 \mu \mathrm{M})$ failed to exert a significant effect on stimulated $\left[{ }^{3} \mathrm{H}\right] \mathrm{ACh}$ release in hippocampal preparations from $\mathrm{M}_{2}$ receptor $\mathrm{KO}$ mice (Fig. $2 B$ ). On the other hand, oxotremorine displayed comparable inhibitory effects on neurotransmitter release in hippocampal preparations from $\mathrm{M}_{4}$ receptor $\mathrm{KO}$ and their WT control mice (Fig. 2C). Similar observations were made when analogous studies were performed with cortical tissues (Fig. 3). As observed with hippocampal preparations, oxotremorine failed to inhibit stimulated $\left[{ }^{3} \mathrm{H}\right] \mathrm{ACh}$ release in cortical slices from $\mathrm{M}_{2}$ receptor $\mathrm{KO}$ mice (Fig. $3 B$ ) but showed similar activities in cortical preparations from $\mathrm{M}_{4}$ receptor $\mathrm{KO}$ and their WT control mice (Fig. 3C). These findings strongly suggest that the $\mathrm{M}_{2}$ subtype represents the predominant muscarinic autoreceptor in mouse hippocampus and cerebral cortex.

\section{The $M_{4}$ subtype functions as the major muscarinic autoreceptor in striatum}

In striking contrast to the findings obtained with hippocampal and cortical slices, oxotremorine $(0.1-10 \mu \mathrm{M})$ retained the ability to mediate inhibition of stimulated $\left[{ }^{3} \mathrm{H}\right] \mathrm{ACh}$ release in striatal preparations from mice lacking the $\mathrm{M}_{2} \mathrm{mAChR}$ (Fig. 4B). The degree of oxotremorine-induced inhibition of transmitter release was similar in striatal tissues from $\mathrm{M}_{2}$ receptor $\mathrm{KO}$ and their WT control mice (Fig. 4B). In contrast, oxotremorine virtually lacked the ability to inhibit stimulated $\left[{ }^{3} \mathrm{H}\right] \mathrm{ACh}$ release in striatal preparations from mice lacking $\mathrm{M}_{4}$ receptors (Fig. 4C). Although there was a trend to slightly reduced $\left[{ }^{3} \mathrm{H}\right] \mathrm{ACh}$ levels at the two highest oxotremorine concentrations used (1 and $10 \mu \mathrm{M})$ (Fig. $4 C)$, this effect did not reach statistical significance. These data strongly suggest that the $\mathrm{M}_{4}$ subtype represents the major muscarinic autoreceptor in mouse striatum.

\section{Colocalization of $\mathrm{M}_{2}$ and $\mathrm{M}_{4}$ muscarinic receptors with VAChT in the striatum}

It can be argued that the lack of muscarinic autoinhibition of ACh release observed with striatal preparations from $\mathrm{M}_{4}$ receptor KO mice may be caused by alterations in the distribution of $\mathrm{M}_{2}$ receptors at striatal cholinergic terminals. For example, $\mathrm{M}_{2}$ receptors may perhaps act as primary autoreceptors in $\mathrm{M}_{4}$ receptor $\mathrm{WT}$ mice but may no longer localize to cholinergic terminals in $\mathrm{M}_{4}$ receptor $\mathrm{KO}$ mice, thus providing a possible explanation for the lack of autoinhibition of $\mathrm{ACh}$ release observed with striatal preparations from $\mathrm{M}_{4}$ receptor $\mathrm{KO}$ mice. To test this hypothesis, we determined to which extent $\mathrm{M}_{2}$ receptors colocalized with the VAChT, a marker of cholinergic terminals (Gilmor et al., 1996), in the striatum of $\mathrm{M}_{4}$ receptor $\mathrm{WT}$ and $\mathrm{M}_{4}$ receptor $\mathrm{KO}$ mice. As shown in Figure 5, the $\mathrm{M}_{2}$ receptor was colocalized with VAChT in striatal cholinergic terminals in the striatum of both $\mathrm{M}_{4}$ receptor WT and KO mice. Quantitation of confocal images (see Materials and Methods for details) revealed $\sim 8.7 \%( \pm 0.4)$ and $7.1 \%( \pm 0.5)$ colocalization of $\mathrm{M}_{2}$ receptors with VAChT in cholinergic terminals in $\mathrm{M}_{4}$ receptor $\mathrm{WT}$ and $\mathrm{M}_{4}$ receptor $\mathrm{KO}$ mice, respectively. These values represent the minimum degree of colocalization as either marker may be present but may not detectable with the method used here. Because the majority of $\mathrm{M}_{2}$ receptors does not localize to VAChT-positive cholinergic terminals (in either $\mathrm{M}_{4}$ receptor WT or KO mice), 


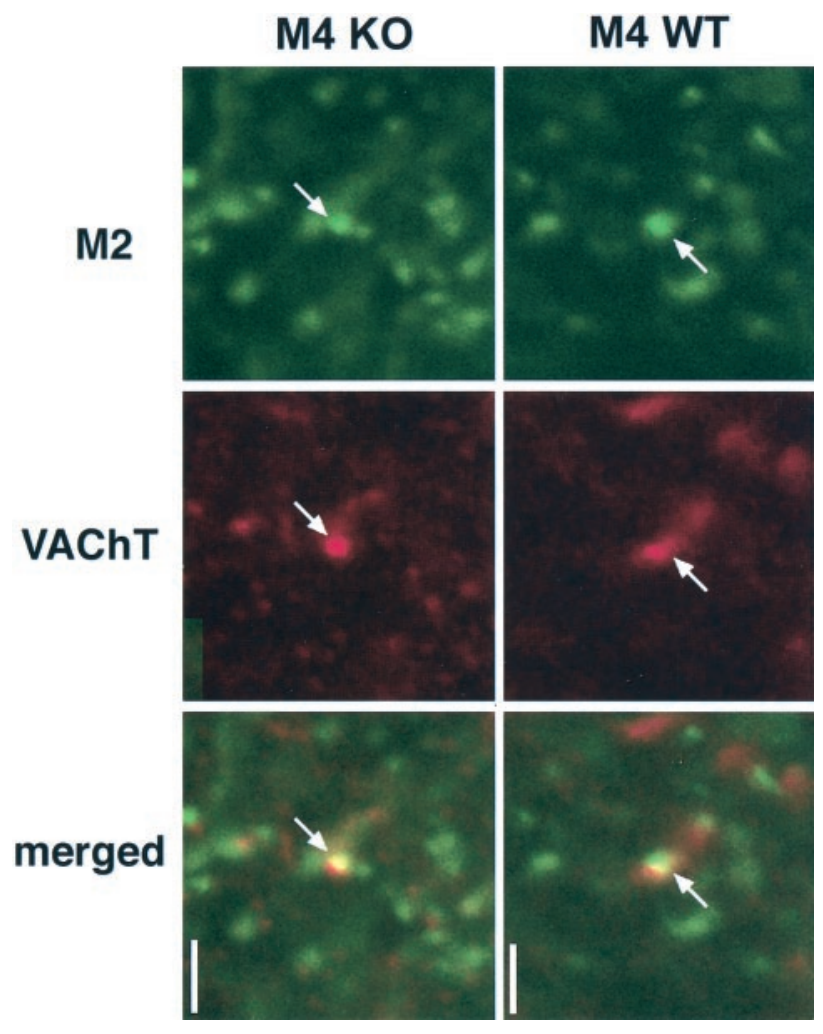

Figure 5. Expression of $\mathrm{M}_{2}$ muscarinic receptors in cholinergic terminals in the striatum of $\mathrm{M}_{4}$ receptor $\mathrm{WT}$ and $\mathrm{M}_{4}$ receptor $\mathrm{KO}$ mice. Striatal slices ( $\sim 50$-mm-thick) were prepared from $\mathrm{M}_{4}$ receptor $\mathrm{WT}$ or $\mathrm{M}_{4}$ receptor $\mathrm{KO}$ mice, and the $\mathrm{M}_{2}$ muscarinic receptor and the VAChT were visualized via confocal immunofluorescence microscopy (see Materials and Methods for details). $\mathrm{M}_{2}$ receptors (green) colocalize with VAChT (red) in some cholinergic terminals in both $\mathrm{M}_{4}$ receptor WT and KO mice. Colocalization is visualized as yellow in the merged images (arrows). Scale bars, $2 \mu \mathrm{m}$.

most of the $\mathrm{M}_{2}$ receptor immunoreactivity is likely to represent $\mathrm{M}_{2}$ receptors present on aspiny dendrites of cholinergic interneurons or $\mathrm{M}_{2}$ receptors localized to terminals of noncholinergic, excitatory synapses (Hersch et al., 1994). In any case, our data clearly show that the lack of $\mathrm{M}_{4}$ receptors does not lead to a redistribution of $\mathrm{M}_{2}$ receptors on cholinergic terminals in the striatum.

Because the neurochemical studies suggested that $M_{4}$ receptors function as muscarinic autoreceptors in the striatum, we also determined to which extent $\mathrm{M}_{4}$ receptors colocalized with VAChT in striatal cholinergic terminals. Quantitation of confocal microscopic images indicated that $\sim 6.5 \%( \pm 0.3)$ of $\mathrm{M}_{4}$ receptors colocalized with VAChT in cholinergic terminals (Fig. 6). Similar to $\mathrm{M}_{2}$ receptors, most of the striatal $\mathrm{M}_{4}$ receptors do not localize to cholinergic terminals $\left(\mathrm{M}_{4}\right.$ receptors are predominately found on dendritic spines of striatal projection neurons and also on terminals of asymmetric, excitatory synapses (Hersch et al., 1994; Bernard et al., 1999). It is possible that the level of $\mathbf{M}_{4}$ receptors on striatal cholinergic terminals is lower than on dendrites which could limit the sensitivity of detection of these receptors by immunofluorescence. Taken together, the muscarinic receptor-VAChT colocalization data are consistent with our observation that $\mathrm{M}_{4}$ receptors can act as release-inhibiting autoreceptors in the striatum.

\section{DISCUSSION}

The present study was designed to identify the mAChR subtypes that mediate autoinhibition of $\mathrm{ACh}$ release in various brain regions. Based on the results of functional studies using muscarinic agonists and antagonists of limited mAChR subtype selectivity, considerable controversy exists regarding which specific mAChRs represent the primary inhibitory autoreceptors in different regions of the CNS (see introductory remarks for more details). To avoid the pitfalls associated with the use of classical pharmacological tools (ligands), we decided to study $\left[{ }^{3} \mathrm{H}\right] \mathrm{ACh}$ release using brain slices from different $\mathrm{mAChR} \mathrm{KO}$ strains. Specifically, we examined the nature of the inhibitory muscarinic autoreceptors in hippocampus, cerebral cortex, and striatum, using tissues prepared from $\mathrm{M}_{2}-\mathrm{M}_{4}$ receptor double $\mathrm{KO}$ and $\mathrm{M}_{2}$ and $\mathrm{M}_{4}$ receptor single $\mathrm{KO}$ mice (and their corresponding WT controls). The $\mathrm{M}_{2}$ and $\mathrm{M}_{4} \mathrm{mAChRs}$ (but not the $\mathrm{M}_{1}, \mathrm{M}_{3}$, and $\mathrm{M}_{5}$ mAChRs) are efficiently coupled to G-proteins of the $\mathrm{G}_{\mathrm{i}} / \mathrm{G}_{\mathrm{o}}$ family (Hulme et al., 1990; Caulfield, 1993; Wess, 1996) that are predicted to play a role in the inhibition of neurotransmitter release via inhibition of voltage-sensitive $\mathrm{Ca}^{2+}$ channels (Caulfield, 1993; Shapiro et al., 1999). It seemed therefore reasonable to assume that $\mathrm{M}_{2}$ and/or $\mathrm{M}_{4}$ receptors are the most likely candidates involved in autoinhibition of ACh release.

By using a strategy similar to that described here (use of mutant mice lacking specific $\alpha_{2}$-adrenergic receptor subtypes), recent studies have identified specific adrenergic receptor subtypes mediating autoinhibition of electrically stimulated norepinephrine release in several central and peripheral tissues (Trendelenburg et al., 1999, 2001).

\section{The $\mathrm{M}_{2}$ receptor subtype represents the predominant inhibitory muscarinic autoreceptor in hippocampus and cerebral cortex}

We initially performed $\left[{ }^{3} \mathrm{H}\right] \mathrm{ACh}$ release studies using superfused brain slices derived from $\mathrm{M}_{2} / \mathrm{M}_{4}$ receptor double $\mathrm{KO}$ and their WT control mice. These experiments showed that oxotremorineinduced inhibition of potassium-stimulated $\left[{ }^{3} \mathrm{H}\right] \mathrm{ACh}$ release was totally abolished in hippocampal, cortical, and striatal preparations from $\mathrm{M}_{2}-\mathrm{M}_{4}$ receptor double $\mathrm{KO}$ mice (Figs. $2 A, 3 A, 4 A$ ).

To examine whether autoinhibition of $\mathrm{ACh}$ release was mediated by $\mathrm{M}_{2}$ or $\mathrm{M}_{4}$ receptors (or by a mixture of the two receptors), we next performed analogous studies with tissues from $\mathrm{M}_{2}$ and $\mathrm{M}_{4}$ receptor single $\mathrm{KO}$ mice. In hippocampal and cortical preparations, the lack of $\mathrm{M}_{4}$ receptors had no significant effect on agonist-dependent inhibition of stimulated $\left[{ }^{3} \mathrm{H}\right] \mathrm{ACh}$ release (Figs. $2 C, 3 C$ ). In contrast, in hippocampal and cortical preparations from $\mathrm{M}_{2}$ receptor $\mathrm{KO}$ mice, this activity was completely abolished (Figs. 2B, 3B). These observations demonstrate in a direct and unambiguous manner that the $\mathrm{M}_{2}$ subtype represents the predominant muscarinic autoreceptor in hippocampus and cerebral cortex. This observation is consistent with highresolution microscopic studies indicating that the $\mathrm{M}_{2}$ receptor is abundantly expressed on cholinergic nerve terminals in the hippocampus (Rouse et al., 2000). Moreover, a recent in vivo microdialysis study using antisense oligodeoxynucleotides to reduce the expression levels of $\mathrm{M}_{2}$ or $\mathrm{M}_{4}$ receptors also arrived at the conclusion that hippocampal inhibitory muscarinic autoreceptors primarily consist of $\mathbf{M}_{2}$ receptors (Kitaichi et al., 1999).

Reduced levels of $\mathrm{ACh}$ are consistently found in cerebral cortex and hippocampus of patients suffering from Alzheimer's disease, and considerable evidence suggests that this neurochemical deficit makes a major contribution to the cognitive impair- 

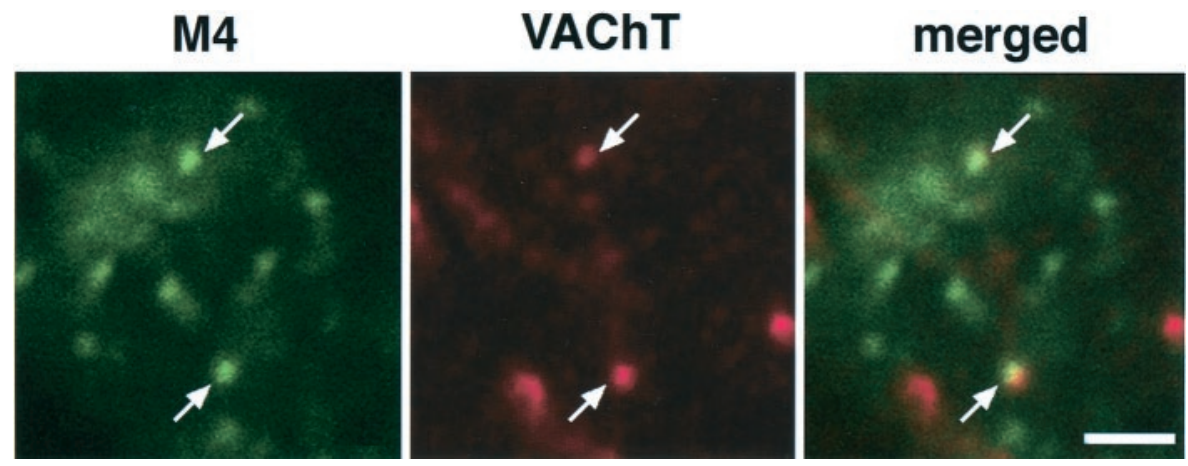

Figure 6. Localization of $\mathrm{M}_{4}$ muscarinic receptors to cholinergic terminals in mouse striatum. Striatal slices ( $\sim 50$-mm-thick) were prepared from $\mathrm{M}_{4}$ receptor WT mice, and the $\mathrm{M}_{4}$ muscarinic receptor and the VAChT were visualized via confocal immunofluorescence microscopy (see Materials and Methods for details). $\mathrm{M}_{4}$ receptors (green) colocalize with VAChT (red) in some cholinergic terminals. Colocalization is visualized as yellow in the merged images (arrows). Scale bar, $2 \mu \mathrm{m}$.

ments associated with this disease (Coyle et al., 1983; Mash et al., 1985; Quirion et al., 1989; McKinney and Coyle, 1991). Because pharmacological blockade of hippocampal and cortical presynaptic $\mathrm{M}_{2}$ autoreceptors is predicted to lead to an increase in synaptic ACh levels because of disruption of autoinhibition of ACh release, our results strongly support the concept that centrally active $\mathrm{M}_{2}$ receptor antagonists may become useful in the treatment of Alzheimer's disease. In agreement with this notion, several laboratories have demonstrated that muscarinic antagonists endowed with high-affinity for $\mathrm{M}_{2}$ (and $\mathrm{M}_{4}$ ) $\mathrm{mAChRs}$ can facilitate learning and memory in experimental animals (Quirion et al., 1989, 1995; Lachowicz et al., 2001).

\section{The $M_{4}$ receptor subtype represents the primary inhibitory muscarinic autoreceptor in the striatum}

Properly regulated muscarinic neurotransmission in the striatum is known to play an important role in the regulation of extrapyramidal locomotor activity (Di Chiara et al., 1994). Most notably, a misbalance between muscarinic and dopaminergic neurotransmission in the striatum is considered a hallmark of Parkinson's disease (Hornykiewicz, 1981; Fahn et al., 1990). Identification of the mAChR subtype that mediates autoinhibition of ACh release in the striatum is therefore of considerable therapeutic interest. In contrast to what we observed with hippocampal and cortical tissues, oxotremorine-induced inhibition of stimulated $\left[{ }^{3} \mathrm{H}\right] \mathrm{ACh}$ release remained largely intact in striatal slices from $\mathrm{M}_{2}$ receptor $\mathrm{KO}$ mice (Fig. 4B). On the other hand, oxotremorine virtually lost its ability to mediate inhibition of stimulated $\left[{ }^{3} \mathrm{H}\right] \mathrm{ACh}$ release in striatal slices from $\mathrm{M}_{4}$ receptor $\mathrm{KO}$ mice (Fig. $4 C$ ). These data clearly demonstrate that the $\mathrm{M}_{4}$ subtype represent the predominant inhibitory muscarinic autoreceptor in mouse striatum. Because centrally active muscarinic antagonists are widely used in the treatment of Parkinson's disease (Fahn et al., 1990; Standaert and Young, 1996), our findings should be of considerable therapeutic relevance.

Previous studies have shown that $\mathrm{M}_{2}$ muscarinic receptors are abundantly expressed in striatal cholinergic interneurons (Hersch et al., 1994; Bernard et al., 1998). These neurons are known to provide the source of striatal ACh and innervate virtually all striatal projection neurons (Di Chiara et al., 1994). It has therefore been proposed that muscarinic autoinhibition of striatal ACh release may be mediated predominantly by $\mathrm{M}_{2}$ receptors (Hersch et al., 1994; Bernard et al., 1998). However, as discussed in the previous paragraph, our neurochemical data strongly suggest that the $\mathrm{M}_{4}$ receptor subtype represents the primary inhibitory muscarinic autoreceptor in mouse striatum. Immunoprecipitation studies showed that the lack of $\mathrm{M}_{4}$ receptors in $\mathrm{M}_{4}$ receptor $\mathrm{KO}$ mice had no significant effect on $\mathrm{M}_{2}$ receptor expression levels in the striatum (Gomeza et al., 1999b). Similarly, disruption of the $M_{2}$ receptor gene had no noticeable effect on overall striatal $M_{4}$ receptor densities (Gomeza et al., 1999a). In addition, immunofluorescence studies demonstrated that both $\mathrm{M}_{2}$ and $\mathrm{M}_{4}$ receptors are colocalized with VAChT, a marker of cholinergic terminals (Gilmor et al., 1996), in the striatum (Figs. 5, 6). This observation is consistent with previous findings indicating that both $\mathrm{M}_{2}$ and $\mathrm{M}_{4}$ receptors are expressed by most striatal cholinergic interneurons (Bernard et al., 1992, 1998, 1999; Hersch et al., 1994; Yan and Surmeier, 1996). However, to the best of our knowledge, this is the first study demonstrating the presence of $\mathrm{M}_{4}$ receptors on cholinergic terminals in the striatum. Moreover, $\mathrm{M}_{2}$ receptor/ VAChT double labeling studies showed that the lack of $\mathbf{M}_{4}$ receptors had not significant effect on the pattern of $\mathrm{M}_{2}$ receptor expression on cholinergic terminals in the striatum (Fig. 5). These data therefore exclude the possibility that the lack of muscarinic autoinhibition observed with striatal preparations from $\mathrm{M}_{4}$ receptor $\mathrm{KO}$ mice is an artifact caused by altered $\mathrm{M}_{2}$ receptor expression levels or altered $\mathrm{M}_{2}$ receptor distribution.

To verify that potassium-stimulated $\left[{ }^{3} \mathrm{H}\right]$ outflow in mouse striatal slices primarily represented radiolabeled $\mathrm{ACh}$, we used a reverse HPLC method to separate $\left[{ }^{3} \mathrm{H}\right] \mathrm{ACh}$ from $\left[{ }^{3} \mathrm{H}\right]$ choline (Fig. 1A). This analysis showed that $>90 \%$ of the potassiumstimulated $\left[{ }^{3} \mathrm{H}\right]$ overflow in the striatum consisted of authentic ACh (Fig. 1B, Table 1), thus excluding the possibility that the preferential release of radiolabeled compounds other than $\left[{ }^{3} \mathrm{H}\right] \mathrm{ACh}$ may have affected the outcome of the neurochemical studies in the striatum.

Taken together, both the neurochemical and receptor localization data support the concept that $\mathrm{M}_{4}$ muscarinic receptors act as inhibitory muscarinic autoreceptors in the mouse striatum. Because $\mathrm{M}_{2}$ receptors are also present on the terminals of cholinergic striatal interneurons (see Discussion), it remains unclear at present why muscarinic autoinhibition of striatal ACh release was not significantly affected by the absence of $\mathrm{M}_{2}$ receptors. One possibility is that a potential contribution of $\mathrm{M}_{2}$ receptors to muscarinic autoinhibition of striatal ACh release may have been masked by the presence of the functionally predominant $\mathrm{M}_{4}$ receptors in the $\mathrm{M}_{2}$ receptor $\mathrm{KO}$ mice. In contrast to $\mathrm{M}_{2}$ receptors, $\mathrm{M}_{4}$ receptors are abundantly expressed by a subpopulation of striatal projection neurons (Hersch et al., 1994; Bernard et al., 1999). At present, we cannot completely rule out the possibility that the absence of these receptors may have contributed, through an indirect mechanism, to the loss of muscarinic autoinhibition in striatal slices from $\mathrm{M}_{4}$ receptor $\mathrm{KO}$ mice, e.g., by altering the release of other neurotransmitters such as GABA or glutamate.

In conclusion, our results demonstrate that mAChR KO mice 
represent highly useful tools to assess the molecular identity of the mAChRs that mediate autoinhibition of ACh release in different regions of the brain. We provide direct evidence that the $\mathrm{M}_{2}$ subtype represents the predominant inhibitory muscarinic autoreceptor in hippocampus and cerebral cortex, whereas the $\mathrm{M}_{4}$ receptor subtype functions as the primary inhibitory muscarinic autoreceptor in striatum. These results provide a rational basis for the development of novel muscarinic drugs for a variety of pathophysiological conditions including Alzheimer's and Parkinson's disease. Moreover, our findings suggest that it should be possible to design therapeutic strategies aimed at selectively modulating $\mathrm{ACh}$ release in distinct regions of the brain.

\section{REFERENCES}

Bernard V, Normand E, Bloch B (1992) Phenotypical characterization of the rat striatal neurons expressing muscarinic receptor genes. J Neurosci 12:3591-3600.

Bernard V, Laribi O, Levey AI, Bloch B (1998) Subcellular redistribution of $\mathrm{m} 2$ muscarinic acetylcholine receptors in striatal interneurons in vivo after acute cholinergic stimulation. J Neurosci 18:10207-10218.

Bernard V, Levey AI, Bloch B (1999) Regulation of the subcellular distribution of $\mathrm{m} 4$ muscarinic acetylcholine receptors in striatal neurons in vivo by the cholinergic environment: evidence for regulation of cell surface receptors by endogenous and exogenous stimulation. J Neurosci 19:10237-10249.

Billard W, Binch III H, Crosby G, McQuade RD (1995) Identification of the primary muscarinic autoreceptor subtype in rat striatum as $\mathrm{m}_{2}$ through a correlation of in vivo microdialysis and in vitro receptor binding data. J Pharmacol Exp Ther 273:273-279.

Buckley NJ, Bonner TI, Buckley CM, Brann MR (1989) Antagonist binding properties of five cloned muscarinic receptors expressed in CHO-K1 cells. Mol Pharmacol 35:469-476.

Büyükuysal RL, Ulus IH, Kiran BK (1998) Age-related alterations in pre-synaptic and receptor-mediated cholinergic functions in rat brain. Neurochem Res 23:719-726.

Caulfield MP (1993) Muscarinic receptors - characterization, coupling and function. Pharmacol Ther 58:319-379.

Coyle JT, Price DL, DeLong MR (1983) Alzheimer's disease: a disorder of cortical cholinergic innervation. Science 219:1184-1190.

De Boer P, Westerink BH, Rollema H, Zaagsma J, Horn AS (1990) An $\mathrm{M}_{3}$-like muscarinic autoreceptor regulates the in vivo release of acetylcholine in rat striatum. Eur J Pharmacol 179:167-172.

Di Chiara G, Morelli M, Consolo S (1994) Modulatory functions of neurotransmitters in the striatum: ACh/dopamine/NMDA interactions. Trends Neurosci 17:228-233.

Dolezal V, Tucek S (1998) The effects of brucine and alcuronium on the inhibition of $\left[{ }^{3} \mathrm{H}\right]$ acetylcholine release from rat striatum by muscarinic receptor agonists. Br J Pharmacol 124:1213-1218.

Dörje F, Wess J, Lambrecht G, Tacke R, Mutschler E, Brann M (1991) Antagonist binding profiles of five cloned human muscarinic receptor subtypes. J Pharmacol Exp Ther 256:727-733.

Fahn S, Burke R, Stern Y (1990) Antimuscarinic drugs in the treatment of movement disorders. Prog Brain Res 84:389-397.

Gilmor ML, Nash NR, Roghani A, Edwards RH, Yi H, Hersch SM, Levey AI (1996) Expression of the putative vesicular acetylcholine transporter in rat brain and localization in cholinergic synaptic vesicles. J Neurosci 16:2179-2190.

Gomeza J, Shannon H, Kostenis K, Felder C, Zhang L, Brodkin J, Grinberg A, Sheng H, Wess J (1999a) Pronounced pharmacologic deficits in M2 muscarinic acetylcholine receptor knock-out mice. Proc Natl Acad Sci USA 96:1692-1697.

Gomeza J, Zhang L, Kostenis K, Felder C, Bymaster F, Brodkin J, Shannon H, Xia B, Deng C, Wess J (1999b) Enhancement of D1 dopamine receptor-mediated locomotor stimulation in $\mathbf{M}_{4}$ muscarinic acetylcholine receptor knock-out mice. Proc Natl Acad Sci USA 96:10483-10488.

Hamilton SE, Loose MD, Qi M, Levey AI, Hille B, McKnight GS, Idzerda RL, Nathanson NM (1997) Disruption of the m1 receptor gene ablates muscarinic receptor- dependent $\mathrm{M}$ current regulation and seizure activity in mice. Proc Natl Acad Sci USA 94:13311-13316.

Hersch SM, Gutekunst CA, Rees HD, Heilman CJ, Levey AI (1994) Distribution of $\mathrm{m} 1-\mathrm{m} 4$ muscarinic receptor proteins in the rat striatum: light and electron microscopic immunocytochemistry using subtypespecific antibodies. J Neurosci 14:3351-3363.

Hornykiewicz O (1981) Brain neurotransmitter changes in Parkinson's disease. In: Movement disorders (Marsden DC, Fahn S, eds), pp 41-58. Boston: Butterworth.

Hulme EC, Birdsall NJM, Buckley NJ (1990) Muscarinic receptor subtypes. Annu Rev Pharmacol Toxicol 30:633-673.

James MK, Cubeddu LS (1987) Pharmacologic characterization and functional role of muscarinic autoreceptors in the rabbit striatum. J Pharmacol Exp Ther 240:203-215.

Kawashima K, Hayakawa T, Kashima Y, Suzuki T, Fujimoto K, Oohata $\mathrm{H}$ (1991) Determination of acetylcholine release in the striatum of anesthetized rats using in vivo microdialysis and a radioimmunoassay. J Neurochem 57:882-887.

Kilbinger H (1984) Presynaptic muscarinic receptors modulating acetylcholine release. Trends Pharmacol Sci 7:103-105.

Kitaichi K, Hori T, Srivastava LK, Quirion R (1999) Antisense oligodeoxynucleotides against the muscarinic $\mathrm{m} 2$, but not $\mathrm{m} 4$, receptor supports its role as autoreceptors in the rat hippocampus. Brain Res Mol Brain Res 67:98-106.

Lachowicz JE, Duffy RA, Ruperto V, Kozlowski J, Zhou G, Clader J, Billard W, Binch H, III, Crosby G, Cohen-Williams M, Strader CD, Coffin V (2001) Facilitation of acetylcholine release and improvement in cognition by as elective $\mathrm{M}_{2}$ muscarinic antagonist, $\mathrm{SCH} 72788$. Life Sci 68:2585-2592.

Lapchak P, Araujo D, Quirion R, Collier B (1989) Binding sites for $\left[{ }^{3} \mathrm{H}\right] \mathrm{AF}-\mathrm{DX} 116$ and effect of AF-DX 116 on endogenous acetylcholine release from rat brain slices. Brain Res 496:285-294.

Levey AI (1993) Immunological localization of m1-m5 muscarinic acetylcholine receptors in peripheral tissues and brain. Life Sci 52:441-448.

Levey AI, Kitt CA, Simonds WF, Price DL, Brann MR (1991) Identification and localization of muscarinic acetylcholine receptor proteins in brain with subtype-specific antibodies. J Neurosci 11:3218-3226.

Marchi M, Ruelle A, Andrioli GC, Raiteri M (1990) Pirenzepineinsensitive muscarinic autoreceptors regulate acetylcholine release in human neocortex. Brain Res 520:347-350.

Mash DC, Flynn DD, Potter LT (1985) Loss of M2 muscarine receptors in the cerebral cortex in Alzheimer's disease and experimental cholinergic denervation. Science 228:1115-1117.

McKinney M, Coyle JT (1991) The potential for muscarinic receptor subtype-specific pharmacotherapy for Alzheimer's disease. Mayo Clin Proc 66:1225-1237.

McKinney M, Miller JH, Aagaard PJ (1993) Pharmacological characterization of the rat hippocampal muscarinic autoreceptor. J Pharmacol Exp Ther 264:74-78.

Pedata F, Giovannelli L, De Sarno P, Pepeu G (1986) Effect of adenosine, adenosine derivatives, and caffeine on acetylcholine release from brain synaptosomes: interaction with muscarinic autoregulatory mechanisms. J Neurochem 46:1593-1598.

Pittel Z, Heldman E, Rubinstein R, Cohen S (1990) Distinct muscarinic receptor subtypes differentially modulate acetylcholine release from corticocerebral synaptosomes. J Neurochem 55:665-672.

Pohorecki R, Head R, Domino EF (1988) Effects of selected muscarinic cholinergic antagonists on $\left[{ }^{3} \mathrm{H}\right]$ acetylcholine release from rat hippocampal slices. J Pharmacol Exp Ther 244:213-217.

Quirion R, Aubert I, Lapchak PA, Schaum RP, Teolis S, Gauthier S, Araujo DM (1989) Muscarinic receptor subtypes in human neurodegenerative disorders: focus on Alzheimer's disease. Trends Pharmacol Sci Suppl:80-84.

Quirion R, Wilson A, Rowe W, Aubert I, Richard J, Doods H, Parent A White N, Meaney MJ (1995) Facilitation of acetylcholine release and cognitive performance by an $\mathrm{M}_{2}$-muscarinic receptor antagonist in aged memory-impaired rats. J Neurosci 15:1455-1462.

Raiteri M, Marchi M, Maura G, Bonanno G (1989) Presynaptic regulation of acetylcholine release in the CNS. Cell Biol Int Rep 13:1109-1118.

Rouse ST, Edmunds SM, Yi H, Gilmor ML, Levey AI (2000) Localization of $\mathrm{M}_{2}$ muscarinic acetylcholine receptor protein in cholinergic and non-cholinergic terminals in rat hippocampus. Neurosci Lett 284:182-186.

Schnell SA, Staines WA, Wessendorf MW (1999) Reduction of lipofuscin-like autofluorescence in fluorescently labeled tissue. J Histochem Cytochem 47:719-730.

Shapiro MS, Loose MD, Hamilton SE, Nathanson NM, Gomeza J, Wess J, Hille B (1999) Assignment of muscarinic receptor subtypes mediating $\mathrm{G}$-protein modulation of $\mathrm{Ca}^{2+}$ channels by using knock-out mice. Proc Natl Acad Sci USA 96:10899-10904.

Standaert DG, Young AB (1996) Treatment of central nervous system degenerative disorders. In: Goodman \& Gilman's: The pharmacological basis of therapeutics, Ed 9 (Hardman JG, Limbird LE, eds), pp 503-519. New York: McGraw-Hill.

Starke K, Gothert M, Kilbinger H (1989) Modulation of neurotransmitter release by presynaptic autoreceptors. Pharmacol Rev 69:864-989.

Trendelenburg AU, Hein L, Gaiser EG, Starke K (1999) Occurrence, pharmacology and function of presynaptic $\alpha_{2}$-autoreceptors in $\alpha_{2 \mathrm{~A} / \mathrm{D}^{-}}$ adrenoceptor-deficient mice. Naunyn Schmiedebergs Arch Pharmacol 360:540-551

Trendelenburg AU, Norenberg W, Hein L, Meyer A, Starke K (2001) $\alpha_{2}$-adrenoceptor-mediated inhibition of cultured sympathetic neurons: changes in $\alpha_{2 \mathrm{~A} / \mathrm{D}}$-adrenoceptor-deficient mice. Naunyn Schmiedebergs Arch Pharmacol 363:110-119. 
Vannucchi MG, Pepeu G (1995) Muscarinic receptor modulation of acetylcholine release from rat cerebral cortex and hippocampus. Neurosci Lett 190:53-56.

Vilaro MT, Mengod G, Palacios JM (1993) Advances and limitation of the molecular neuroanatomy of cholinergic receptors: the example of multiple muscarinic receptors. Prog Brain Res 98:95-101.

Vilaro MT, Palacios JM, Mengod G (1994) Multiplicity of muscarinic autoreceptor subtypes? Comparison of the distribution of cholinergic cells and cells containing mRNA for five subtypes of muscarinic receptors in the rat brain. Mol Brain Res 21:30-46.

Weiler M (1989) Muscarinic modulation of endogenous acetylcholine release in rat neostriatal slices. J Pharmacol Exp Ther 250:617623.
Wess J (1996) Molecular biology of muscarinic acetylcholine receptors. Crit Rev Neurobiol 10:69-99.

Wessler I, Werhand J (1990) Evaluation by reverse phase HPLC of $\left[{ }^{3} \mathrm{H}\right]$ acetylcholine release evoked from the myenteric plexus of the rat. Naunyn Schmiedebergs Arch Pharmacol 341:510-516.

Yamada M, Miyakawa T, Duttaroy A, Yamanaka A, Moriguchi T, Makita R, Ogawa M, Chou CJ, Xia B, Crawley JN, Felder C, Deng C, Wess J (2001) Mice lacking the M3 muscarinic acetylcholine receptor are hypophagic and lean. Nature 410:207-212.

Yan Z, Surmeier DJ (1996) Muscarinic (m2/m4) receptors reduce Nand P-type $\mathrm{Ca}^{2+}$ currents in rat neostriatal cholinergic interneurons through a fast, membrane-delimited, G-protein pathway. J Neurosci 16:2592-2604. 